\title{
Determination of Puberty Onset in Bulgarian Murrah Buffalo Heifers through Blood Progesterone Analysis
}

\author{
Planski Vladimir $^{1}$, Yotov Stanimir ${ }^{2 *}$, Karadaev Manol $^{2}$, Ilieva Yordanka ${ }^{3}$, \\ Hristov Kalin ${ }^{1}$ and Dimitrov Dimiter ${ }^{1}$
}

${ }^{1}$ Department of Surgery, Roentgenology, Obstetrics and Gynecology, Faculty of Veterinary

Medicine, University of Forestry, Sofia, Bulgaria

${ }^{2}$ Department of Obstetrics, Reproduction and Reproductive Disorders, Faculty of Veterinary

Medicine, Trakia University, Stara Zagora, Bulgaria

${ }^{3}$ Agricultural Academy, Sofia, Agricultural Institute, Shumen, Bulgaria

*Corresponding author

\section{A B S T R A C T}

The aim of the present research was to evaluate the potential of blood progesterone $\left(\mathrm{P}_{4}\right)$ analysis for determination of puberty onset in Bulgarian Murrah buffalo heifers. The experiment was conducted with 13 clinically healthy buffalo heifers from the Bulgarian

\section{Keywords}

Buffalo heifer, puberty, progesterone.

\section{Article Info}

Accepted:

18 December 2016

Available Online:

10 January 2017 Murrah breed, at 9 to 20 months of age. Blood samples were collected from all animals and progesterone concentrations were assayed through a commercial ELISA. The time course of blood progesterone was monitored in ascending age order and the correlation between both parameters was evaluated. On the basis of hormonal analysis data, the animals were divided into two groups: non-cycling $\left(\mathrm{P}_{4}<1 \mathrm{ng} / \mathrm{ml}\right)$ and cycling $\left(\mathrm{P}_{4}>1\right.$ $\mathrm{ng} / \mathrm{ml}$ ). The percentages of cycling, resp. non-cycling heifers, the average age and mean blood progesterone concentrations in the groups were calculated. Data were statistically analysed. The earliest age at which blood progesterone accepted as threshold value for cycling buffalo heifers was measured, was 11 months. There was a tendency towards increase in the average age of cycling vs. that of non-cycling buffalo heifers with statistically significant difference $(\mathrm{P}<0.001)$ between progesterone concentrations in the two groups. The analysis of results demonstrated that the assay of blood progesterone concentrations in Bulgarian Murrah buffalo heifers could be used for detection of puberty onset. Blood hormonal concentrations were lower than $0.71 \pm 0.24 \mathrm{ng} / \mathrm{ml}$ and higher than $1.23 \pm 0.16 \mathrm{ng} / \mathrm{ml}$ in animals having attained 20 months of age could be assumed as a sign for lack or presence of ovarian activity, respectively. The presented results could contribute to the body of knowledge on endocrine changes of the studied buffalo breed during the prepubertal period and the time of sexual maturity onset.

\section{Introduction}

The determination of puberty onset in buffalo heifers is essential for their inclusion in breeding programs and optimization of reproduction in this animal species. The age of puberty differs and is influenced by a number of factors - climatic and geographical region, breed, season of birth, feeding etc. (Peeva et al., 1993; Borghese et al., 1996; Terzano et al., 1997; Campanile et al., 2001; Singh et al., 2010; Roy et al., 2016). 
According to Jainudeen and Hafez (1993) river buffaloes exhibit first estrus at 15-18 months of age, while swamp buffaloes manifest the first signs of estrus at 21-24 months of age. The studies of different researchers provide proofs for significant variations in the time of puberty onset from 9.9 months in Egyptian buffalo heifers (Mohamed et al.,1980), 18 months of age in Brazilian buffaloes (Okuda et al., 1999), 20.7 months in Mediterranean Italian buffaloes (Borghese et al., 1994) up to 45.5 months in the Surti breed (Sule et al., 2001).

According to Peeva et al. (1993) the onset and course of puberty in buffalo heifers are not completely elucidated as available data are mostly based on visual observations without taking consideration for the endocrinological status of animals. This, however, results in erroneous evaluations due to the numerous factors known to inhibit the expression of estrous behaviour. On the basis of observations, the first estrus in local Bulgarian buffalo heifers is registered at 21 months of age, while RIA blood progesterone $\left(\mathrm{P}_{4}\right)$ analysis in Murrah and its crosses with Bulgarian buffaloes indicate 19.9 months of age as puberty onset. The synopsis of the various reports related to puberty onset in buffalo heifers made by Kanchev et al., (2010) affirmed that the puberty in Murrah buffaloes begins at 14.4 months of age, while in primitive breeds - at 35.6 months of age. Baychev (2008) discussed the effect of season of birth of buffalo heifers on puberty onset and reported that animals born in the spring attained puberty for $404.3 \pm 3.9$ days, while those born in the autumn need 543.2 \pm 19.5 days.

In the major part of cases, the onset of puberty is determined retrospectively, on the basis of first calving date (Borghese, 2005), which does not always indicate accurately the exact time of the first estrus. Singh et al.
(2010) reported that some buffalo heifers could remain anestrous for a long time, even when they have attained the puberty age for the breed if the first estrus is anovulatory or the subsequent follicular development is not adequate. Several recent studies (Humblot et al., 2010; Duittoz et al., 2016; Perry, 2016) demonstrate a strong relationship between the environmental changes and the onset and course of puberty in both animals and humans.

The aim of the present research was to evaluate the potential of blood progesterone analysis for determination of puberty onset in Bulgarian Murrah buffalo heifers.

\section{Materials and Methods}

Thirteen clinically healthy female buffalo heifers from the Bulgarian Murrah breed, aged from 9 to 20 months, with average live weight $250 \pm 12 \mathrm{~kg}$ were included in the experiment. They were reared in free stalls, fed concentrate with roughage and had a free access to water.

Blood samples for progesterone analysis were obtained from $V$. jugularis of previously restrained animals. Immediately after the collection, blood was centrifuged at $3000 \mathrm{rpm}$ for $15 \mathrm{~min}$ and separated sera were stored in sterile tubes at $-18{ }^{0} \mathrm{C}$ until analysis. Hormonal concentrations were assays with a commercial Progesterone ELISA Kit (Monobind Inc, Lake Forest USA) with analytical sensitivity of $0.105 \mathrm{ng} / \mathrm{ml}$ and coefficients of variation $<10 \%$. Progesterone levels of individual samples were measured in triplicate and mean arithmetic value of the three measurements was retained as final value.

The dynamics of blood progesterone was monitored in ascending age order and the correlation between both parameters was 
evaluated. On the basis of hormonal analysis data, the animals were divided into two groups: non-cycling $\left(\mathrm{P}_{4}<1 \mathrm{ng} / \mathrm{ml}\right)$ and cycling $\left(\mathrm{P}_{4}>1 \mathrm{ng} / \mathrm{ml}\right)$ (Terzano et al., 2007). The percentages of cycling, resp. non-cycling heifers, the average age and mean blood progesterone concentrations in the groups were calculated.

Data were analysed using statistical software Statistica version 7.0 (Stat-Soft 1984-2000 Inc., Tulsa, OK, USA).

The effects of the different factors on blood progesterone concentrations were evaluated through correlation analysis and analysis of variance (ANOVA), and means between the groups were compared through the post hoc LSD test. The level of significance was set at $\mathrm{P}<0.05$.

\section{Results and Discussion}

The contradictory information about the time of puberty onset in buffalo heifers on the basis of first estrus expression and first calving date presumes the implementation of more accurate methods for detection of the sexual maturity beginning (Borghese, 2005; Duittoz et al., 2016). Some authors (Jain and Pandey, 1983; Zaabel et al., 1994; Singh and Madan, 1998; Terzano et al., 2007) have used for that purpose blood progesterone concentrations while others (Haldar and Prakash, 2005; Abu-Seida, 2016) identify puberty onset after ultrasound detection of yellow body in one of ovaries as well. Zaabel et al. (1994) measured blood progesterone levels in Egyptian buffaloes through a RIA method and reported that prior to puberty (1214 months of age), they were $<1 \mathrm{ng} / \mathrm{ml}$. A similar threshold values was suggested by Terzano et al. (2007), whereas Jain and Pandey establishing cyclicity in 30-month-old Indian Murrah buffalo heifers when their blood progesterone was $0.80 \pm 0.11 \mathrm{ng} / \mathrm{ml}$.
The data from blood hormonal analysis of Bulgarian Murrah heifers demonstrated a tendency ( $\mathrm{R}=0.41)$ to increased progesterone concentrations as age advanced (Fig. 1). For the first time, a progesterone value over the set threshold was established at 11 months of age. This finding agreed with the reports of Mohamed et al. (1980) for puberty onset in buffalo heifers as early as 9.9 months of age and of Zaabel et al. (1994), who observed increased progesterone levels between the $12^{\text {th }}$ $-14^{\text {th }}$ month of life. The reduced progesterone levels in three of animals having attained 13 months of age showed that they were not always a factor indicating the start of cyclicity. In our view, a possible cause for the low concentrations of the assayed hormone could be the lack or the weak ovarian activity despite that the animal was already 13 -months old. Similar anestrous states accompanied with low blood progesterone $(<0.80 \mathrm{ng} / \mathrm{ml})$ were also reported by Jain and Pandey (1983) and Hassan (2005) for prolonged periods after the birth.

Another reason could be the collection of blood sample from the cycling heifer in the periestrous period when blood $\mathrm{P}_{4}$ is low or an inadequate function of the yellow body, specific for the first few cycles of sexually immature animals. In support of this hypothesis, the analysis of Mondal et al. (2010) demonstrated that blood progesterone levels during the periestrous period varied from $0.30 \pm 0.06 \mathrm{ng} / \mathrm{ml}$ to $0.47 \pm 0.07 \mathrm{ng} / \mathrm{ml}$, attaining $1.94 \pm 0.03 \mathrm{ng} / \mathrm{ml}$ in the mid-luteal stage.

The division of buffalo heifers into cycling and non-cycling on the basis of blood progesterone showed a tendency towards increase of the average age (14.2 \pm 3.5 months) of cycling vs that of non-cycling heifers лената (10.9 \pm 1.7 months) (Tabl. 1). The established statistically significant difference $(\mathrm{P}<0.01) \quad$ between progesterone 
concentrations in the two groups was in line with other research reports (Jain and Pandey,1983; Zaabel et al., 1994; Singh and Madan, 2000; Terzano et al., 2007), affirming that non-cycling animals had low blood concentrations of the studied hormone while those having exhibited ovarian activity had higher blood progesterone values.

The registered mean blood progesterone of $0.71 \pm 0.24 \mathrm{ng} / \mathrm{ml}$ could be assumed as a sign of absence of cyclicity in Bulgarian Murrah buffalo heifers. This suggestion is further confirmed by the findings showing that until 10.5 months of age, blood $\mathrm{P}_{4}$ did not exceed
$0.84 \mathrm{ng} / \mathrm{ml}$. According to Jain and Pandey (1983) blood progesterone in non-cycling Indian buffaloes varied from $0.27 \pm 0.07$ to $0.61 \pm 0.15 \mathrm{ng} / \mathrm{ml}$ from birth to 30 months of age, while in non-cycling it was $0.80 \pm 0.11$ $\mathrm{ng} / \mathrm{ml}$ on the average. Low $\mathrm{P}_{4}$ concentrations $(0.32 \pm 0.06 \mathrm{ng} / \mathrm{ml})$ were reported by Singh and Madan (2000) in 32-month-old noncycling Indian Murrah buffalo heifers, and at the same time cycling animals had blood progesterone of $2.24 \pm 0.25 \mathrm{ng} / \mathrm{ml}$ during the luteal stage. In Mediterranean Italian buffalo heifers, Terzano et al. (2007) measured average blood progesterone of $0.42 \pm 0.19$ $\mathrm{ng} / \mathrm{ml}$ prior to puberty onset.

Table.1 Percentage distribution, mean age and progesterone concentrations in buffalo heifers classified as non-cycling and cycling on the basis of blood progesterone analysis.

\begin{tabular}{|l|c|c|c|}
\hline \multirow{2}{*}{\multicolumn{1}{c|}{ Group }} & \multicolumn{3}{|c|}{ Parameters } \\
\cline { 2 - 4 } & \multirow{2}{*}{$\%$} & Age, months & $\mathrm{P}_{4} \mathrm{ng} / \mathrm{ml}$ \\
\cline { 2 - 4 } & & Mean \pm SD & Mean \pm SD \\
\hline Non-cycling $(\mathrm{n}=6)$ & 46.2 & $10.9 \pm 1.7$ & $0.71 \pm 0.24^{\mathrm{a}}$ \\
\hline Cycling $(\mathrm{n}=7)$ & 53.8 & $14.2 \pm 3.5$ & $1.23 \pm 0.16^{\mathrm{b}}$ \\
\hline
\end{tabular}

The values within a column with different superscripts differed significantly at $\mathrm{P}<0.01$

Fig.1 Time course of individual blood progesterone concentrations related to the age of buffalo heifers

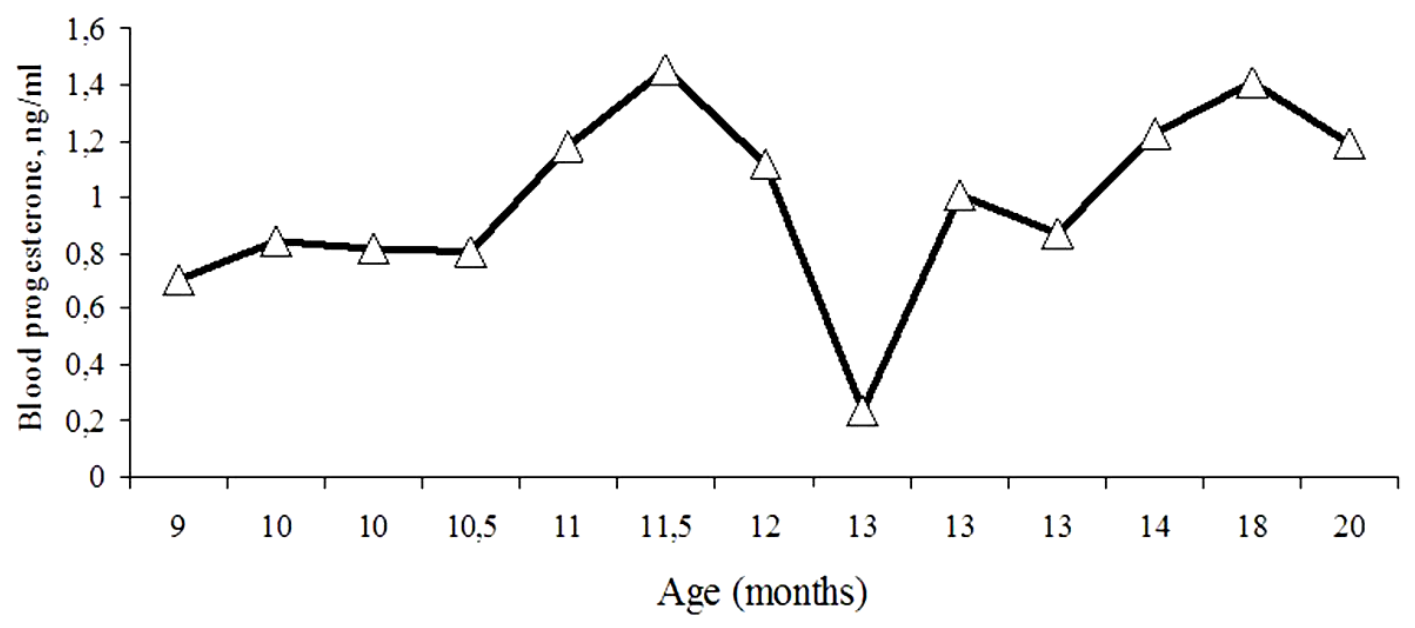


The higher average hormonal concentrations in non-cycling Bulgarian Murrah heifers than values from other reports could be attributed to breed-related differences, geographical location, seasonal influences, effect of rearing technology and the hormonal assay (Terzano et al., 2012). Regardless of all these discrepancies, all aforementioned data substantiate the chosen threshold value of 1 $\mathrm{ng} / \mathrm{ml}$ for classification of animals in the respective groups.

The presented results indicated that blood progesterone concentrations lower than $0.71 \pm 0.24 \mathrm{ng} / \mathrm{ml}$ in Bulgarian Murrah buffalo heifers at average age 14.2 \pm 3.5 months could be associated to the lack of cyclic sexual activity. To avoid he diagnostic error (animals in the periestrous period or such with inadequate luteal function), a repeated analysis after 7 to 10 days is required. An indication of puberty onset on the basis of blood progesterone analysis in animals at the aforementioned age could be the occurrence of concentrations over $1.23 \pm 0.16 \mathrm{ng} / \mathrm{ml}$. In support of this thesis, numerous researchers (Haldar and Prakash, 2005; Singh and Madan, 1998; Terzano et al., 2007) reported that in sexually immature buffalo heifers blood progesterone remained lower than $1 \mathrm{ng} / \mathrm{ml}$, and puberty can occur at a very early age, 9.9 months (Mohamed et al., 1980) or at 12-14 months of age (Zaabel et al., 1994) and was accompanied with ovarian activity.

In conclusion, the assay of blood progesterone concentrations through ELISA in Bulgarian Murrah buffalo heifers could serve to detect the onset of puberty. Hormonal concentrations lower than $0.71 \pm 0.24 \mathrm{ng} / \mathrm{ml}$ and higher than $1.23 \pm 0.16 \mathrm{ng} / \mathrm{ml}$ in animals having reached 20 months of age could be accepted as indicating absence or presence of ovarian activity, respectively. The presented results could contribute to the body of knowledge on endocrine changes of the studied buffalo breed during the prepubertal period and the time of sexual maturity onset.

\section{Acknowledgements}

The authors gratefully acknowledge to Prof. Dr. Zheko Baichev for his support in hormonal analysis accomplishment.

\section{References}

Abu-Seida, A.M. 2016. Current status and prospect of ultrasonographic application in buffaloes. Asian J. Anim. Vet. Adv., 11(2): 144-157.

Baychev, Zh. 2008. The role of melatonin in reproduction and stress in large ruminants. Dissertation, Sofia, Bulgaria, p. 183.

Borghese, A. (Ed.) 2005. In: Technical Series 67. Food and Agriculture Organization, Rome, Italy, pp. 77-79.

Borghese, A., Barile, V.L., Ficco, G., Galasso, A., Marchiori, E., Terzano, G.M. 1997. Feeding system effect on reproduction performances in buffalo heifers. In: Proc. Fifth World Buffalo Congress, Caserta, Italy, 13-16 October, pp. 697-701.

Borghese, A., Terzano, G.M., Barile, V.L., Parmeggiani, A. 1994. Season and feeding level effects on onset of puberty in buffalo heifers. In: Proc. Fourth World Buffalo Congress, Sao Paulo, Brazil, 27-30 June, pp. 525-527.

Borghese, A., Terzano, M.G., Barile, V.L., Catalano, A., Malfatti, A. 1996. Onset of puberty in buffalo heifers in different feeding and management systems. In: Proc. International. Symposium on Buffalo Resources and Production Systems, Cairo, Egypt, 14-17 Octoberq pp. 41-46.

Campanile, G., Di Palo, R., Gasparrini, B., D'Occhio, M.J., Zicarelli, L. 2001. Effects of early management system 
and subsequent diet on growth and conception in buffalo heifers. Livest. Prod. Sci., 71(2/3): 183-191.

Duittoz, A.H., Tillet, Y., Le Bourhis, D., Schibler, L. 2016. The timing of puberty (oocyte quality and management). Anim. Reprod., 13(3): 313-333.

Haldar, A., Prakash, B.S. 2005. Peripheral patterns of growth hormone, luteinizing hormone, and progesterone before, at, and after puberty in buffalo heifer. Endocr. Res., 31(4): 295-306.

Hassan, S.G. 2005. Delayed age of puberty in buffalo heifer. ISAH, Warsaw, Poland, 1: 159-162.

Humblot, P., Le Bourhis, D., Fritz, S., Colleau, J.J., Gonzalez, C., Guyader J.C., Malafosse, A., Heyman, Y., Amigues, Y., Tissier, M., Ponsart, C. 2010. Reproductive technologies and genomic selection in cattle. Vet. Med. Int., 12: 1-8.

Jain, G.C., Pandey R.S. 1983. Changes in the profiles of peripheral plasma progesterone, oestradiol-178 andluteinjzing hormone from birth to puberty following conception in buffalo heifers (bubalus bubalis). Asian I. Dairy Res., 2(4): 227-233.

Jainudeen, M.R., Hafez, E.S.E. 1993. Cattle and Buffalo. In: Hafez E.S.E. (Ed.), Reproduction in Farm Animals, 6th ed., Lea and Febiger, Philadelphia, pp. 315329.

Kanchev, L., Baychev, Zh., Kacheva, D. 2010. Assisted Reproduction Technologies. Sofia, Bulgaria, pp. 2427.

Mohamed, A.A., El-Ashry, M.A., El-Serafy, A.M. 1980. Reproductive performance of buffalo heifers bred at a young age. Indian J. Anim. Sci., 50: 8.

Mondal S, Suresh, K.P., Nandi, S. 2010. Endocrine profiles of oestrous cycle in buffalo: A meta-analysis. Asian-Aust. J.
Anim. Sci., 23(2): 169-174.

Okuda, H.T., Starke Buzetti, W.A., Fagliari, J.J., Passipiéri, M., Zocoller Seno, M.C., Bergamaschine, A.F. 1999. Observations of puberty, age at first calving and calving interval in buffalo cows. Veterinária Notícias, 5(1): 91-96.

Peeva, Ts., Vankov, K., Tsankova, M., Polihronov, O., Dragoev, A., Danev. A. 1993. All for Buffaloes. Agrocomplex Ltd, Sofia, Bulgaria, pp. 61-62.

Perry, G.A., Cushman, R.A. 2016. Invited Review: Use of ultrasonography to make reproductive management decisions. ARPS, 32(2): 154-161.

Roy, A.K., Singh, M., Kumar, P., Kumar, B.S.B. 2016. Effect of extended photoperiod during winter on growth and onset of puberty in Murrah buffalo heifers. Vet. World, 9(2): 216-221.

Singh, C., Madan, M. L. 2000. Effect of PGF2 $a$ and GnRH during different ovarian status at onset of puberty in Murrah buffalo heifers (Bubalus Bubalis). Animal Sci., 13(8): 10591062.

Singh, C., Madan, M.L. 1998. Pituitary and gonadal response to $\mathrm{GnRH}$ in prepubertal buffaloes (Bubalus Bubalis). AJAS, 11(1): 78-83.

Singh, J., Ghuman S.P.S., Dadarwal, D., Honparkhe, M., Dhaliwal, G.S., Jain, A.K. 2010. Estimations of blood plasma metabolites following melatonin implants treatment for initiation of ovarian cyclicity in true anestrus buffalo heifers. Indian J. Anim. Sci., 80 (3): 229-231.

Sule, S.R., Taparia, A.L., Jain, L.S., Tailor, S.P. 2001. Reproductive status of Surti buffaloes maintained under sub-humid conditions of Rajasthan. Indian Vet. J., 78 (11): 1049-1051.

Terzano, G.M., Barile, V.L., Borghese, A. 2012. Overview on reproductive endocrine aspects in buffalo. J. Buffalo 
Sci., 1: 126-138.

Terzano, G.M., Galasso, A., Barile, V.L., Pacelli, C., Montemurro, N., Borghese, A. 1997. Effect of feeding system and puberty on blood metabolites trends in buffalo heifers. In: Proc. Fifth World Buffalo Congress, Caserta, Italy, 13-16 October: 951-956.

Terzano, G.M., Neglia, G., Maschio, M., Barile, V.L., Razzano, M., Martiniello,
P., Cannone, I., Borghese, A. 2007. Effect of intensive or extensive systems on buffalo heifers performances: onset of puberty and ovarian size. Ital. J. Anim. Sci., 6, (Suppl. 2): 1273-1276.

Zaabel, S.M., Hussein S.A., Sharawy, S.M., Serur, B.H. 1994. Estradiol 17- $\beta$ and progesterone profiles in prebubertal buffalo-heifers. $2^{\text {nd }}$ Vet. Med. Congress. Zagazig, Egypt.

\section{How to cite this article:}

Planski Vladimir, Yotov Stanimir, Karadaev Manol, Ilieva Yordanka, Hristov Kalin, Dimitrov Dimiter. 2017. Determination of Puberty Onset in Bulgarian Murrah Buffalo Heifers through Blood Progesterone Analysis. Int.J.Curr.Microbiol.App.Sci. 6(1): 308-314. doi: http://dx.doi.org/10.20546/ijcmas.2017.601.037 